\title{
Exchange of energy, nitrogen and phosphorus between water, bottom and ice in a near-shore ecosystem of the Sea of Japan
}

\author{
M. V. Propp \\ Laboratory of Experimental Hydrobiology, Institute of Marine Biology; \\ Vladivostok, USSR
}

\begin{abstract}
The processes taking place at the partioning boundaries of a marine ecosystem are still rather obscure. At a permanent research station, water (in winter, ice) samples were taken throughout the year from 6 different depths, and 16 variables related to productivity and hydrochemistry were determined. Transparent and black-walled bell jars were installed on the sea bottom at depths ranging from 0 to $10 \mathrm{~m}$ in order to record rates of photosynthesis, respiration and chemical metabolism. In the region studied, two peaks of phytoplankton development occurred: one in winter and one in summer. The winter one coincided with a rise in orthophosphate and nitrate concentrations; the summer peak, with a rise in water temperature and increase of bottom regeneration. Photosynthesis of bottom diatoms was evidenced for all depths investigated. Ammonia and orthophosphate excretion were recorded in all experiments conducted on soft substrata. The measured rates of regeneration corresponded with the values expected in accordance with seasonal changes in nitrogen and phosphorus concentrations. Turnover rates of nitrogen and phosphorus between water and sediment were about 2 to 4 months. Higher production of coastal sea regions may be partly explained by the proximity of the photic layer to sediments and by the increased regeneration rates of biogenous elements.
\end{abstract}

\section{INT'RODUCTION}

Processes that take place on the boundaries between sea and atmosphere, sea ice or bottom, have been studied much less extensively than those in the water column. In spite of the existence of pleuston - a specific population of the sea-surface film - processes occurring on the boundary between sea and atmosphere are mainly physico-chemical (Horne, 1969); they will not be considered here.

While in limnology the importance of metabolic processes between water and sediment has long been widely known, for marine ecosystem, with the exception of littoral ones (Pamatmat, 1968; Banse et a!., 1971; Cadée \& Hegeman, 1974), data on soft-bottom community respiration is not numerous (Hargrave, 1969; Banse et al., 1971; Smith et al., 1972; Smith, 1973); nitrogen metabolic rates have only been measured experimentally in one study (Rowe et al., 1975). 
The object of the present research is a preliminary estimation of the direction and of the scale of energy and chemical turnover on the boundaries in near-shore ecosystems of the Sea of Japan. The hydrochemical regime and primary production of phytoplankton will only be dealt with to the degree required so that metabolic processes are not examined in isolation.

\section{MATERIAL AND METHODS}

At the permanent station in Vostok Bay of the Sea of Japan, water sampling was carried out monthly for a period of 14 months; in winter, ice samples were also taken. Water was collected with a pump of plastic and stainless steel. A polyethelene hose carried it into black polyethylene cans. The samples were taken between 10:00 and 11:00 from depths of respectively $0.3,1,3,5,10$ and $15 \mathrm{~m}$. The depth at the permanent station was 15.5 to $16 \mathrm{~m}$, depending on the tidal phase. Control samples taken at several other stations of the bay, showed little variation. Ice samples obtained with a ring borer were sawed into three layers and, after melting at $20^{\circ} \mathrm{C}$ in a thermostatic bath, analysed in the same way as the samples of water, except for the determination of oxygen. The samples were analysed as to oxygen concentration, salinity, concentration of orthophosphate, dissolved organic and particulate phosphorus, silicate, ammonia, nitrites, nitrates, urea, dissolved and particulate nitrogen, chlorophylls $a, b, c$ and pheophytin A. For mineralisation of organic forms, ultraviolet burning was used (Armstrong et al., 1966); dissolved organic carbon was determined in a number of samples by a photochemical combustion method worked out by Propp \& Propp (in press). Particulate forms of nitrogen and phosphorus were determined on membrane ultrafilters of $0.4 \mathrm{~nm}$ pore size employing oxidation with sulfuric and perchloric acids according to the method worked out in our laboratory. Urea was determined according to Newell et al. (1967). The rest of the analyses were made by methods very similar to those described by Strickland \& Parsons (1972). All samples were analysed in duplicate. The precision obtained corresponds to the data of Strickland \& Parsons; only when determining dissolved organic nitrogen, more serious errors may have occurred, since these values represent the difference between the total nitrogen content and the content of its separate forms; in addition, certain difficulties in the analytical procedure became apparent while carrying out the present study.

Rates of photosynthesis, respiration, as well as nitrogen and phosphorus excretion of bottom communities were determined in several modifications on hard and soft bottoms. Rocky bottom occupies a considerably smaller area in the bay, and the data obtained for this substratum will not be examined here. Transparent and blackened-glass bell jars of two shapes, covering $0.05 \mathrm{~m}^{2}$ of the bottom, were pressed into the sediment on mud and sand (Fig. 1). Up to 10 samples of sediment were taken at each station by glass tubes $4 \mathrm{~cm}$ in diameter without disturbing the stratification of sediment. All field work was done with SCUBA equipment.

Using closed bell jars (Fig. $1 \mathrm{~A}$ ), water samples were taken for determining $\mathrm{O}_{2}$ concentration; we employed a syringe pipette every 3 to $6 \mathrm{~h}$, keeping the jars 
hermetic (Propp et al., 1975). The experiment lasted 5 to 26 hours, depending on water temperature. After terminating the experiment a vacuated bottle was connected to the taps and a sample was taken for chemical analysis of the water.

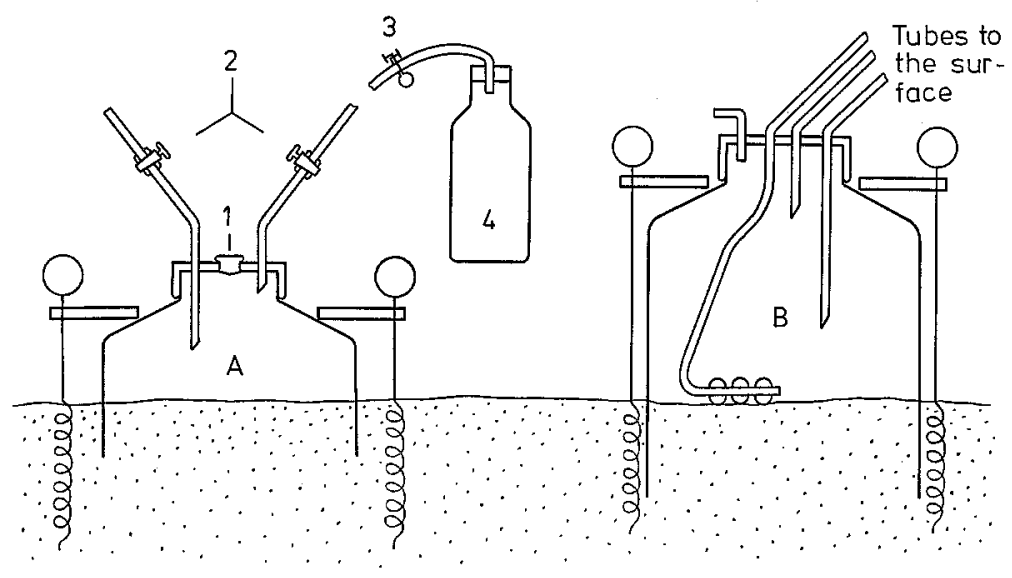

Fig. 1: Closed bell jar (A); flow-through bell jar (B). 1 rubber cork for syringe sampling (oxygen determination); 2 taps for taking samples for chemical analysis of nitrogen, phosphorus and silicate; 3 clamp; 4 vacuated bottle for water sampling

Transparent and black bottles, of the same capacity as the experimental vessels (2 1), and made of the same kind of glass were used as controls; they were placed in two replicates on the bottom next to the jars. Water stratification inside the jars was studied by means of taking a series of water samples for oxygen determination with syringe pipettes with needles of different lengths; the detected differences between the layers did not exceed $0.2 \mathrm{ml} \mathrm{O} 21$. Some vessels were provided with mixers, but their use was given up as the results obtained proved to be unreproduceable.

Tubes, with soft rubber corks at both ends, were incubated both in natural conditions and in tanks with temperature and lighting similiar to those in nature. Considerable differences were not infrequently observed between the data obtained in the tubes and in the jars, so that in our subsequent work only the latter data is made use of, these are more representative.

Following water sample collection, a small sediment sample was taken from each jar for chemical and particle-size analyses, as well as for chlorophyll-content measurement. The remaining sediment was washed through a $1-\mathrm{mm}$ mesh screen, and all the animals larger than $1 \mathrm{~mm}$ were collected, sorted to species, counted and weighed.

In view of the possibility of systematic errors caused by the suction of water from the sediment and by the influence of stratification of the water in the jar, particularly in the case of long exposure, the guided-experiment method of measuring 
in the open-flow water jars was successfully employed (Fig. 1b). Water was drawn to the surface from three levels of each jar by a special six-channel perilstatic pump with PVC hoses and then used for analysis. It was possible to vary the total volume of the sample taken in accordance with the results obtained, so as to combine a
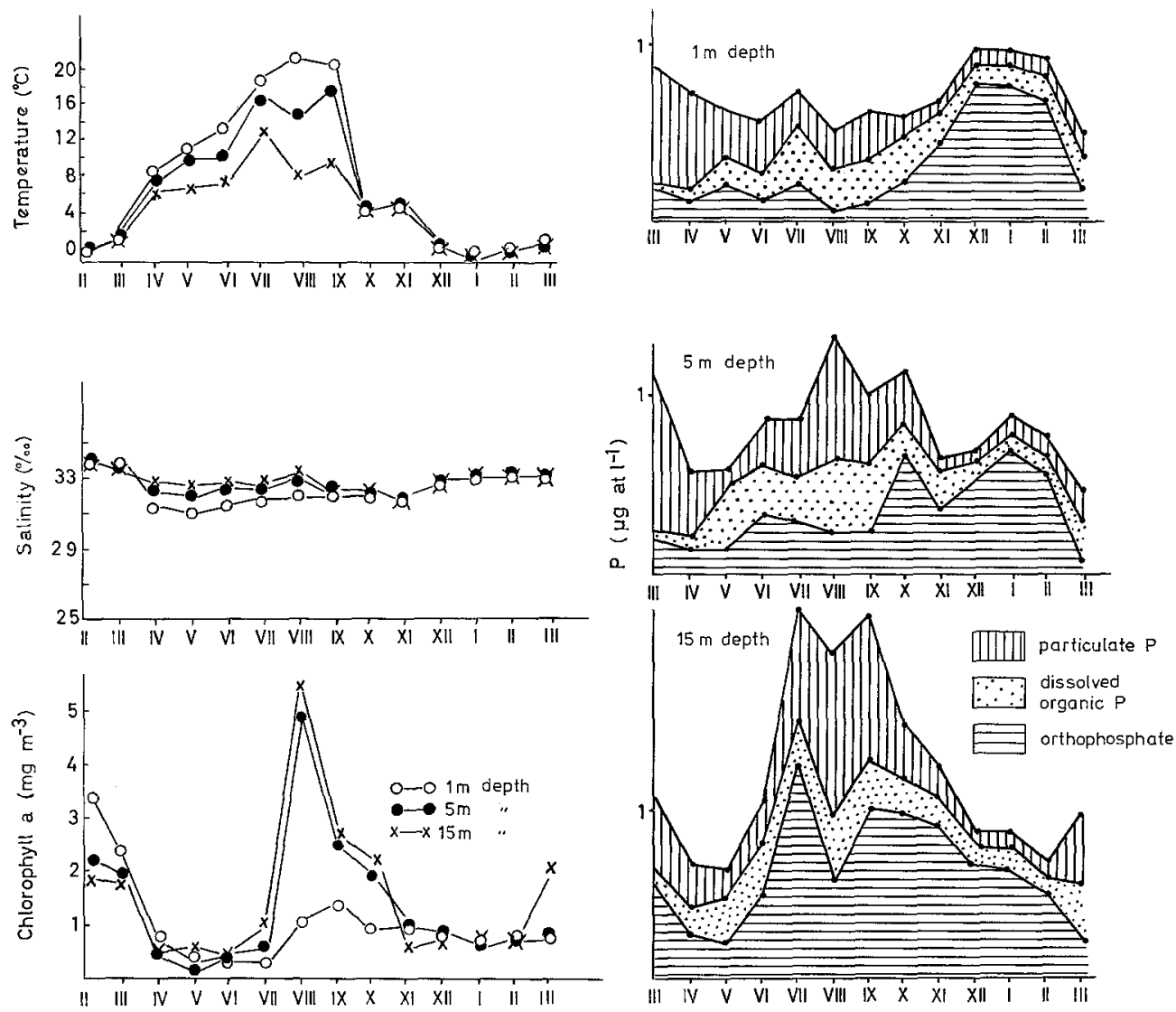

Fig. 2: Seasonal fluctuations of temperature, salinity and chlorophyll $a$ content in Vostock Bay of the Sea of Japan

Fig. 3: Seasonal changes in phosphorus concentration

satisfactory accuracy of basic analytical procedures while preserving inside the vessel concentrations of oxygen, orthophosphate and ammonia not too different from the initial ones. The experiment could be continued over a long period of time, sampling water two or three times a day, but the complexity of arrangement and the multiplicity of analyses permitted the use of this method with but few replicates. So far, no significant differences were observed from the results obtained using the closedjars method. 
When calculating respiration (including chemical oxidation of sediment), the mean values were determined for the time up to the moment when a decrease in breathing rate was observed. In some cases, however, the values for the first period of measuring were found to be very low, which was most likely caused by bottom diatoms escaping into the sediment as a result of manipulation connected with the arrangement of the jars on the bottom. Such values were not taken into account. The rates of photosynthesis were calculated for the light part of the day and do not represent the mean $24 \mathrm{~h}$ values.

\section{RESULTS}

The seasonal fluctuations of temperature, salinity and concentrations of different forms of nitrogen, phosphorus and chlorophyll $a$, at three depths are shown in Figures 2, 3 and 4. Two outbreaks can be observed in the development of phytoplankton: From January to February and from July to September. The winter growth takes place in comparatively uniform water on the background of the preceding accumulation of orthophosphate and nitrate. The summer outbreak is characterised by a pronounced stratification of water and a sharp impoverishment in biogenic elements of the upper part of photic layer.

The dynamics of hydrochemical and productional indices for the sea ice and the water layer beneath (Fig. 4), reveal a mass growth of microalgae in the lower ice layer, one month before these algae establish mass population in the main water mass. The total contribution of the ice population to productional and metabolic processes is not large because of the thinness of the ice and the limited areas which it occupies. However, the ice-covered areas, estuaries and eutrophied parts of the bay constitute the sources from which the winter growth of phytoplankton begins spreading to eventually reach near-shore marine waters.

The total stock of nitrogen and phosphorus in a $15-\mathrm{m}$ thick layer of water, calculated with due regard for the thickness of separate layers with a known concentration, undergoes marked and regular changes in the course of the year (Fig. 5), so does the quantity of chlorophyll. During the winter development of phytoplankton one can observe a gradual decrease in the stock of nitrogen and phosphorus in the water, the minimum being reached in April and May. In contrast the summer outbreak is followed by the accumulation of nitrogen and phosphorus in the water, the total autumn stock of these being approximately three times larger than in spring. If the stock of these elements were determined only by processes occurring in plankton, we might expect it to remain at the same level.

As a result of the measurements made (Table 1 ) both respiration and photosynthesis rates of bottom communities were estimated (Table 2, flow-jar experiments excluded). On soft bottoms excretion of ammonia and orthophosphate was discovered in all cases, although it varied in intensity (Table 2). Turnover rates of other forms of nitrogen and phosphorus were much weaker and no statistically reliable values could be obtained, though it is possible that urea is excreted and that there is also exchange of nitrate in autumn and winter. In some cases, excretion and absorption 
of silicate could be observed, however these materials should be checked on with the help of plastic vessels. In any case, low concentrations of nitrogen and phosphorus are not a limiting factor for bottom-diatom growth.

Table 1

Experimental determination of metabolic rates of bentic communities (numerator: black vessels, denominator: transparent vessels). n.d.: not determined

\begin{tabular}{|c|c|c|c|c|c|c|}
\hline Date & $\begin{array}{l}\text { Depth } \\
(\mathrm{m})\end{array}$ & $\begin{array}{c}\text { Number } \\
\text { of } \\
\text { vessels }\end{array}$ & Sediment & $\begin{array}{c}\text { Prevalent } \\
\text { taxonomic } \\
\text { groups }\end{array}$ & $\begin{array}{c}\text { Mean } \\
\text { animal } \\
\text { density } \\
\text { (ind. } \mathrm{m}^{-2} \text { ) }\end{array}$ & $\begin{array}{c}\text { Mean } \\
\text { animal } \\
\text { biomass } \\
\text { (wet weight } \\
\mathrm{g} \mathrm{m}^{-2} \text { ) }\end{array}$ \\
\hline \multicolumn{7}{|l|}{1975} \\
\hline 17 Sept. & 0.5 & $\begin{array}{l}1 \\
2\end{array}$ & $\begin{array}{l}\text { sand, } \\
\text { shingle }\end{array}$ & n.d. & n.d. & n.d. \\
\hline 17 Sept. & 3 & $\begin{array}{l}1 \\
2\end{array}$ & $\begin{array}{l}\text { sand, } \\
\text { mud }\end{array}$ & n.d. & n.d. & n.d. \\
\hline 17 Sept. & 6 & $\begin{array}{l}1 \\
2\end{array}$ & mud & n.d. & n.d. & n.d. \\
\hline 25 Sept. & 0.5 & $\begin{array}{l}1 \\
2\end{array}$ & mud & n.d. & n.d. & n.d. \\
\hline 27 Nov. & 0.5 & $\begin{array}{l}1 \\
2\end{array}$ & shingle & $\begin{array}{l}\text { Cirripedia, } \\
\text { Polychaeta }\end{array}$ & $\begin{array}{r}18 \\
265\end{array}$ & $\begin{array}{l}20 \\
14\end{array}$ \\
\hline 27 Nov. & 5 & $\begin{array}{l}1 \\
2\end{array}$ & $\begin{array}{l}\text { mud, } \\
\text { sand }\end{array}$ & $\begin{array}{l}\text { Bivalvia, } \\
\text { Polychaeta }\end{array}$ & $\begin{array}{l}765 \\
592\end{array}$ & $\begin{array}{l}53 \\
51\end{array}$ \\
\hline 27 Nov. & 10 & $\frac{2}{2}$ & mud & Bivalvia & $\begin{array}{l}2143 \\
3862\end{array}$ & $\begin{array}{r}68 \\
243\end{array}$ \\
\hline \multicolumn{7}{|l|}{1976} \\
\hline 28 Feb. & 1 & $\begin{array}{l}2 \\
2\end{array}$ & $\begin{array}{l}\text { mud, } \\
\text { shingle }\end{array}$ & $\begin{array}{l}\text { Polychaeta, } \\
\text { Cirripedia }\end{array}$ & $\begin{array}{r}30 \\
0\end{array}$ & $\begin{array}{l}5.7 \\
0\end{array}$ \\
\hline 28 Feb. & 5 & $\frac{2}{2}$ & mud & Bivalvia & $\begin{array}{l}993 \\
706\end{array}$ & $\begin{array}{l}30 \\
83\end{array}$ \\
\hline 28 Feb. & 10 & $\begin{array}{l}2 \\
2\end{array}$ & mud & $\begin{array}{l}\text { Polychaeta, } \\
\text { Bivalvia }\end{array}$ & $\begin{array}{l}4795 \\
2910\end{array}$ & $\begin{array}{l}110 \\
101\end{array}$ \\
\hline \multicolumn{7}{|l|}{1975} \\
\hline 31 Oct. & 0.5 & $\begin{array}{l}1 \\
2\end{array}$ & sand & & $\begin{array}{l}0 \\
0\end{array}$ & $\begin{array}{l}0 \\
0\end{array}$ \\
\hline 31 Oct. & 5 & $\begin{array}{l}1 \\
2\end{array}$ & sand & $\begin{array}{l}\text { Ophiuroidea, } \\
\text { Bivalvia }\end{array}$ & $\begin{array}{l}285 \\
204\end{array}$ & $\begin{array}{l}18 \\
12\end{array}$ \\
\hline 31 Oct. & 10 & $\begin{array}{l}1 \\
2\end{array}$ & $\begin{array}{l}\text { sand, } \\
\text { silt }\end{array}$ & Bivalvia & $\begin{array}{l}1265 \\
2102\end{array}$ & $\begin{array}{r}99 \\
100\end{array}$ \\
\hline 14 Apr. & 0.5 & $\begin{array}{l}2 \\
2\end{array}$ & sand & & $\begin{array}{l}0 \\
0\end{array}$ & $\begin{array}{l}0 \\
0\end{array}$ \\
\hline 14 Apr. & 5 & $\begin{array}{l}2 \\
2\end{array}$ & sand & n.d. & n.d. & n.d. \\
\hline 14 Apr. & 10 & $\begin{array}{l}2 \\
2\end{array}$ & $\begin{array}{l}\text { sand, } \\
\text { mud }\end{array}$ & $\begin{array}{l}\text { Bivalvia, } \\
\text { Polychaeta }\end{array}$ & $\begin{array}{r}908 \\
1163\end{array}$ & $\begin{array}{l}251 \\
207\end{array}$ \\
\hline
\end{tabular}


Table 2

Chlorophyll content, photosynthesis, respiration, as well as ammonia and orthophosphate excretion for benthic communities. For energy metabolism the nominator stands for photosynthesis, the denominator for respiration $\left(\mathrm{ml} \mathrm{O}_{2} \mathrm{~m}^{-2} \mathrm{~h}^{-1}\right)$. Excretion data are for transparent and black vessels respectively $\left(\mu \mathrm{g}\right.$-at. $\mathrm{m}^{-2}$ day $\left.{ }^{-1}\right)$. Chlorophyll $a\left(\mathrm{mg} \mathrm{m}^{-2}\right)$. n.d.: not determined

\begin{tabular}{|c|c|c|c|c|c|c|c|}
\hline Date & $\begin{array}{c}\text { Depth } \\
(\mathrm{m})\end{array}$ & $\begin{array}{l}\text { Tempera- } \\
\text { ture }\left({ }^{\circ} \mathrm{C}\right)\end{array}$ & $\begin{array}{c}\text { Total } \\
\text { duration } \\
\text { (h) }\end{array}$ & $\begin{array}{l}\text { Chloro- } \\
\text { phyll } \\
\text { content }\end{array}$ & $\begin{array}{c}\text { Energy } \\
\text { meta- } \\
\text { bolism }\end{array}$ & Ammonia & $\begin{array}{l}\text { Excretion } \\
\text { of ortho- } \\
\text { phosphate }\end{array}$ \\
\hline \multicolumn{8}{|l|}{1975} \\
\hline 17 Sept. & 0.5 & 19.6 & 17.5 & n.d. & $\begin{array}{l}38.4 \\
13.5\end{array}$ & n.d. & n.d. \\
\hline 17 Sept. & 3 & 19.5 & 18.5 & n.d. & $\begin{array}{r}8.5 \\
27.5\end{array}$ & n.d. & n.d. \\
\hline 17 Sept. & 6 & 19.5 & 17.5 & n.d. & $\begin{array}{r}0.3 \\
14.9\end{array}$ & n.d. & n.d. \\
\hline 25 Sept. & 0.5 & 20.4 & 6 & n.d. & $\begin{array}{c}21.4 \\
9\end{array}$ & $\begin{array}{r}120 \\
1600\end{array}$ & $\begin{array}{l}230 \\
170\end{array}$ \\
\hline 27 Nov. & 0.5 & 5.2 & 26 & n.d. & $\begin{array}{l}6.9 \\
7.5\end{array}$ & $\begin{array}{r}62 \\
106\end{array}$ & $\begin{array}{l}14 \\
69\end{array}$ \\
\hline 27 Nov. & 5 & 5.2 & 9 & n.d. & $\begin{array}{r}-6.5 \\
9.5\end{array}$ & $\begin{array}{r}21 \\
158\end{array}$ & $\begin{array}{l}32 \\
10\end{array}$ \\
\hline 27 Nov. & 10 & 5.2 & 9 & n.d. & $\begin{array}{r}-6.3 \\
6.3\end{array}$ & $\begin{array}{r}355 \\
14\end{array}$ & $\begin{array}{r}160 \\
6\end{array}$ \\
\hline \multicolumn{8}{|l|}{1976} \\
\hline $28 \mathrm{Feb}$ & 1 & -1.6 & 26 & n.d. & $\begin{array}{l}2.9 \\
1.3\end{array}$ & $\begin{array}{l}464 \\
590\end{array}$ & $\begin{array}{l}10 \\
13\end{array}$ \\
\hline 28 Feb. & 5 & -1.6 & 26 & $\begin{array}{l}50 \\
63\end{array}$ & $\begin{array}{l}2.2 \\
2.8\end{array}$ & $\begin{array}{l}512 \\
158\end{array}$ & $\begin{array}{l}48 \\
51\end{array}$ \\
\hline 28 Feb. & 10 & -1.6 & 26 & $\begin{array}{r}6 \\
15\end{array}$ & $\begin{array}{l}2.7 \\
3.6\end{array}$ & $\begin{array}{l}360 \\
303\end{array}$ & $\begin{array}{l}50 \\
22\end{array}$ \\
\hline \multicolumn{8}{|l|}{1975} \\
\hline 31 Oct. & 0.5 & 4.6 & 30 & n.d. & $\begin{array}{l}1.0 \\
0.5\end{array}$ & $\begin{array}{r}265 \\
3\end{array}$ & $\begin{array}{l}13 \\
14\end{array}$ \\
\hline 31 Oct. & 5 & 4.8 & 28 & n.d. & $\begin{array}{r}-0.6 \\
6.4\end{array}$ & $\begin{array}{r}140 \\
80\end{array}$ & $\begin{array}{r}9 \\
13\end{array}$ \\
\hline 31 Oct. & 10 & 4.8 & 10 & n.d. & $\begin{array}{l}3.6 \\
7.5\end{array}$ & $\begin{array}{r}31 \\
4\end{array}$ & $\begin{array}{l}18 \\
20\end{array}$ \\
\hline \multicolumn{8}{|l|}{1976} \\
\hline 14 Apr. & 0.5 & 2.8 & 9 & $\begin{array}{l}53 \\
\text { n.d. }\end{array}$ & $\begin{array}{r}-0.7 \\
1.7\end{array}$ & $\begin{array}{l}114 \\
\text { n.d. }\end{array}$ & $\begin{array}{l}10 \\
\text { n.d. }\end{array}$ \\
\hline 14 Apr. & 5 & 2.8 & 9 & $\begin{array}{l}607 \\
610\end{array}$ & $\begin{array}{r}-1.2 \\
2.2\end{array}$ & $\begin{array}{r}197 \\
23\end{array}$ & $\begin{array}{l}18 \\
0,5\end{array}$ \\
\hline 14 Apr. & 10 & 2.8 & 9 & $\begin{array}{l}425 \\
212\end{array}$ & $\begin{array}{l}5.5 \\
7.4\end{array}$ & $\begin{array}{r}33 \\
180\end{array}$ & $\begin{array}{r}7 \\
12\end{array}$ \\
\hline
\end{tabular}



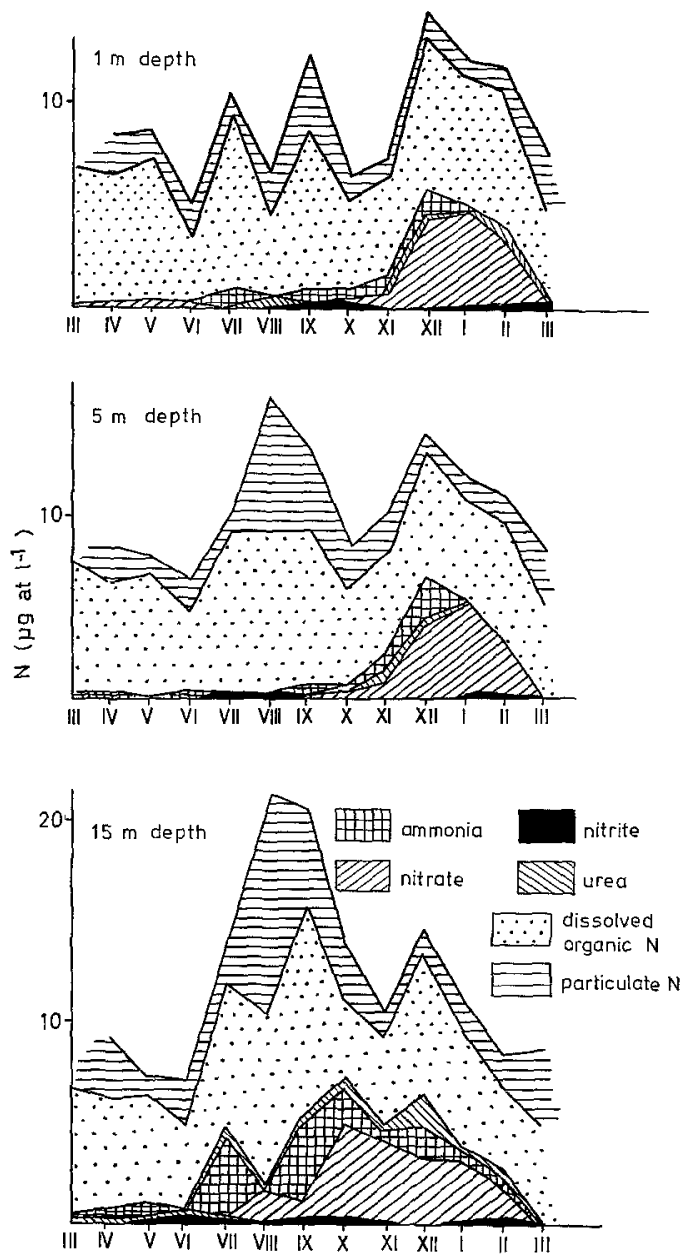

Fig. 4: Seasonal changes in nitrogen concentration

\section{DISCUSSION}

The essential problems for further discussion are: (1) the extent to which the near-shore ecosystem of the bay is open; (2) the amount of warer exchange between bay and sea; and (3) the role played by river inflow. A noticeable influence of fresh waters has been discovered only in regard to silicate concentrations in the uppermost layer of the sea water and, in some places, enrichment in nitrogen and phosphorus quite close to the estuaries. The water exchange between bay and sea is irregular and is greatly increased at the time of stormy winds and typhoons; it can be tentatively assumed that the mean time of water exchange covers no less than 14 to 30 days. Some irregularities in seasonal fluctuations of hydrochemical data (Figs. 2, 3 and 4) 
are probably connected to changes in water exchange. However, since the bay waters are similiar in composition to those of the sea, the importance of the water exchange is not so great as that of the inner processes going on in the ecosystem.
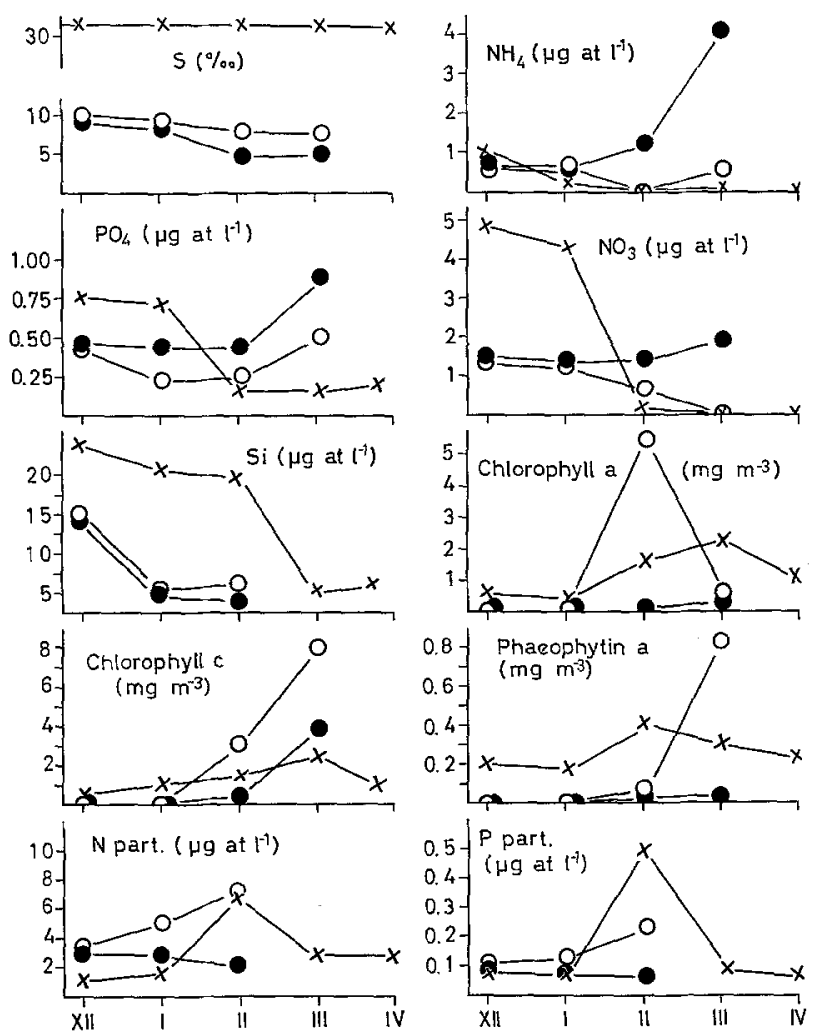

Fig. 5: Chemical and productional characteristics of the sea ice and near-ice layer of surface seawater in April. - surface ice layer; $\bigcirc$ lower ice layer; $X$ near-ice water layer

Considerable changes in metabolic rates of bottom communities are connected with the joint effect of a number of factors: (1) the slowness of the diffusion of oxygen and biogene materials from the bottom into the water; (2) the influence of resuspension in the surface layer of the sediments; (3) heterogenous distribution of the bottom population; and (4) consumption of ammonia and orthophosphate during photosynthesis of bottom algae and their mobility in the upper sediment layer. For the above reasons, the integral metabolic rates measured do not show close connection between the factors mentioned and the values obtained, with the exception of the role of sediment type and temperature. In view of the fact that there is a considerable number of variables and a great dispersion, while the number of experiments is small, no regularities except obvious ones can be discovered by statistical analysis. In contrast to Rowe's data (Rowe et al., 1975), no general cor- 
respondence between respiration of bottom communities and rate of ammonia excretion was detected.

The values for bottom-community respiration conform to those previously determined by other authors (Pamatmat \& Fenton, 1968; Hargrave, 1969; Smith, 1973; Hargrave, 1975; Pamatmat, 1975) and do not show great differences between sandy and muddy grounds in terms of metabolic rates. Still, the rates of photosynthesis and the chlorophyll-a content on sand is noticeably higher than on mud while the ammonia and orthophosphate excretion rates are lower. Both these differences are correlated with a more intense development of microflora and a faster circulation of biogenous elements on sands. Sedimentation and resuspension is more marked on muds.

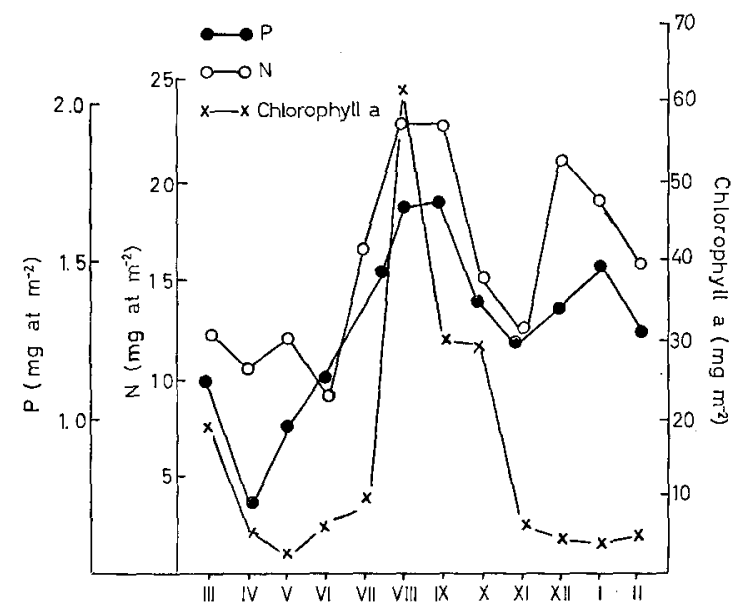

Fig. 6: Seasonal fluctuations of total phosphorus, nitrogen and chlorophyll a stock in a $15-\mathrm{m}$ thick water layer

Here only the orders of the magnitude of energy and chemical metabolism are worth considering. The total stock of phosphorus and nitrogen was determined in a 15-m thick water column, this is about the average depth of the bay (Fig. 6). A comparison of monthly changes of the total stock of nitrogen and phosphorus in the water, reflecting the differences between sedimentation and excretion by the bottom communities, shows that these are values of the same order of magnitude (Tables 2, 3). Consequently, the observed changes in the total stock may be fully accounted for by phytoplankton growth, sedimentation and bottom regeneration, though it is more probable that the exchange of water between the bay and sea is of some importance too.

The high productivity of the neritic waters is connected to a considerable degree with the proximity of the border seabed water to the photic layer and with the rapidity of the nitrogen and phosphorus circulation. The phosphorus turnover time between water and bottom is about 2 to 4 months. It is more difficult to determine the corresponding value for nitrogen, as a considerable part of dissolved organic 
Table 3

Monthly changes in total nitrogen and phosphorus stock in $15-\mathrm{m}$ thick water layer ( $\mu \mathrm{g}-\mathrm{at}^{-2} \mathrm{day}^{-1}$ )

\begin{tabular}{|crrrrrrr}
\hline Months & I & II & III & IV & V & VI \\
\hline $\begin{array}{l}\text { Nitrogen } \\
\text { Phosphorus }\end{array}$ & -110 & -106 & $\begin{array}{l}-53 \\
-6\end{array}$ & $\begin{array}{l}+46 \\
+5\end{array}$ & $\begin{array}{l}+106 \\
+10\end{array}$ & $\begin{array}{l}+267 \\
+\end{array}$ \\
\hline Months & VII & VIII & IX & X & XI & XII \\
\hline $\begin{array}{l}\text { Nitrogen } \\
\text { Phosphorus }\end{array}$ & +23 & -2 & -246 & -93 & +320 & -100 \\
\hline
\end{tabular}

nitrogen is in the form of compounds whose role and dynamics in the ecosystem are insufficiently known. If it is assumed that one third of dissolved organic nitrogen is represented by aminoacids (Antia et al., 1975), and that the latter circulate with about the same intensity as ammonia (Eppley et al., 1973), one may suppose the mean turnover rate of nitrogen to be a value of the same order as that of phosphorus.

As a rule the water in Vostok Bay is turbid and poorly illuminated; at depths exceeding $5 \mathrm{~m}$ a noticeable rate of photosynthesis on mud was recorded only during short periods of rather transparent water. In more transparent areas a rather higher primary production can prevail. In Vostok Bay, according to a rather tentative estimation, the primary production of bottom microalgae amounts to not more than 20 to $30 \%$ of that of phytoplankton, and is less important for the entire ecosystem than the regeneration of dissolved phosphorus and ammonia in the bottom communities.

Since the most probable turnover rates of phosphorus and nitrogen in plankton have the magnitude of days or weeks (Eppley et al., 1973; Sorokin \& Vishkwortzev, 1975 ), the processes occurring at the boundary waterbottom are approximately one order slower in magnitude than those in plankton. However, as they change the total stock of these substances in the water, it is highly probable that they may act as regulators of the productional process in a nearshore marine ecosystem. The data obtained conform better to the assumption that the regeneration of nitrogen and phosphorus serve as a major regulatory mechanism in marine ecosystem (Collier et al., 1973) than to the concept of the flow of chemical elements being more or less proportional to the main energy flow (Bruce, 1973).

It should be noted that oil pollution, insecticides and heavy metals, accumulating in marine sediments, may considerably affect the metabolic rates of bottom communities, and as a result of this, the production of the whole ecosystem.

\section{METHODICAL PROBLEMS}

While the study of primary production of phytoplankton has a long history, measurements of bottom-community metabolic rates are in their initial stage. The 
methods employed are rather complex and the adequacy of the data obtained is doubtful. It is quite probable that indirect indices such as ATP or chlorophyll content, concentration of myramic acid (Moriarty, 1975), activity of enzymes of the electron-transfer chain or of separate ferment systems, will prove to be more convenient than directly measured rates of energy exchange and metabolism. However, it remains necessary to compare these values with direct measurements. There is a number of unsolved problems: (1) Stirring of the water and the upper layer of the sediment, changes metabolic rates. Sedimentation and resuspension are of paramount importance in bottom ecology (Pomeroy, 1960; Rhoads, 1973). Both by artificial stirring in experimental vessels and by omitting it, natural conditions are distorted. (2) Diffusion in the sediment is extremely slow. Some authors have used formaldehyde and antibiotics in order to stop metabolic processes partially or completely (Smith, 1973; Pamatmat, 1975). In our experiments, the addition of $40 \%$ formaldehyde to the content of the tubes caused the death of all animals only after three days as it penetrated the sediment very slowly. In short-term experiments such substances reduce metabolism only partially; on the other hand, the conditions in long term experiments differ too much from the natural ones. (3) In many cases, bottom communities are extremely heterogeneous and the values obtained in different vessels are not comparable.

Although at present not all methodological problems can be solved satisfactorily, it seems that the flowing vessel and the guided experiment constitute a step forward. Unfortunately these techniques are too complicated for routine work. Still, even rough estimations of processes taking place at the boundary between water and bottom or ice facilitates better understanding of the peculiarities of the neritic ecosystem.

\section{LITERATURE CITED}

Antia, N. L., Berland, B. R., Bonin D. J. \& Maestrini, S. V., 1975. Comparative evaluation of certain organic and inorganic sources of nitrogen for phototrophic growth of marine microalgae. J. mar. biol. Ass. U. K. 55, 519-539.

Armstrong, F. A., Williams, P. M. \& Strickland, J.D. H., 1966. Photooxidation of organic matter in sea water by ultraviolet radiation, analytical and other applications. Nature, Lond. 211, 481-483.

Banse, K., Nichols, F. H. \& May, D. R., 1971. Oxygen consumption by the seabed. III. On the role of macrofauna at three stations. Vie Mileu (Suppl.) 22 (1), 31-52.

Bruce, H., 1973. The structure of ecosystems. J. theor. Biol. 41, 535-546.

Cadée, G. C. \& Hegeman, J., 1974. Primary production of the benthic microflora living on tidal flats in the Dutch Wadden Sea. Neth. J. Sea Res. 8, 260-291.

Collier, B. D., Cox, G. W., Johnson, A. W. \& Miller, P. C., 1973. Dynamic ecology. Prentice Hall Inc., Englewood-Cliffs, N. Y., 563 pp.

Colocoloff, M. \& Colocoloff, C., 1973. Recherches sur la production primaire d'un fond sableux. 2. Méthodes. Tethys. 4, 779-800.

Eppley, R. W., Wenger, E. H., Venric, E. L. \& Mullin, M. M., 1973. A study of plankton dynamics and nutrient cycling in the central gyre of the North Pacific Ocean. Limnol. Oceanogr. 14, 801-805.

Hargrave, B. T., 1969. Similarity of oxygen uptake by benthic communities. Limnol. Oceanogr. 14, 801-805. 
- 1973. Coupling carbon flow through some pelagic and benthic communities. J. Fish. Res. Bd Can. 30, 1317-1326.

Horne, R. A., 1969. The structure of water and the chemistry of the hydrosphere. Wiley Interscience, New York, 398 pp.

Moriarty, D. J. W. 1975. A method for estimating the biomass of bacteria in aquatic sediments and its application to trophic studies. Oecologia 20, 219-229.

Newell, B. S., Morgan, B. \& Cundy, J., 1967. The determination of urea in sea water. J. mar. Res. 25, 201-202.

Pamatmat, M. M., 1968. Ecology and metabolism of a benthic community on an intertidial sandflats. Int. Revue ges. Hydrobiol. 53, 211-298.

- 1975. In situ metabolism of benthic communities. Cah. biol. mar. 16 (Suppl.), 613-633.

- Fenton, D., 1968. An instrument for measuring subtidal metabolism in situ. Limnol. Oceanogr. 13, 537-540.

Propp, M. V. \& Propp, L. N. The determination of dissolved organic matter in sea water by ultraviolet combustion. Okeanologija (Russ.) (In press.).

- Denisov, V. B., Pogrebov, V. B. \& Ryabushko, V. I., 1975. Ecosystem of the Barent Sea Fiord. I. Hydrological and hydrochemical characteristics. Biol. Morja (Russ.) 3, 44-57.

Rhoads, D. C., 1973. The influence of deposit-feeding benthos on water turbidity and nutrient recycling. Am. J. Sci. 273, 1-22.

Rowe, G. T., Hovey, C. C., Smith, K. L. \& Lawrence, H. P., 1975. Benthic nutrient regeneration and its coupling to primary productivity in coastal waters. Nature, Lond. 255, 215-217.

Smith, K. L., 1973. Respiration of a sublittoral community. Ecology 54, 1065-1075.

- Burn, K. A. \& Teal, J. M., 1972. In situ respiration of benthic communities in Castle Harbour, Bermuda. Mar. Biol. 12, 196-199.

Sorokin, J. I. \& Vishkvortzev, D. I., 1973. Consumption of mineral phosphate by a planktonic community in tropical waters. Okeanologija (Russ.) 14, 688-692.

Strickland, J. D. H. \& Parsons, T. R., 1972. A practical handbook of seawater analysis. Bull. Fish. Res. Bd Can. 167, 1-310.

Wheeler, P. A., North, B. B. \& Stephens, G. C., 1974. Aminoacids uptake by marine phytoplankters. Limnol. Oceanogr. 19, 249-259.

Author's address: M. V. Propp

Laboratory of Experimental Hydrobiology

Institute of Marine Biology

Vladivostok 690022

USSR 